\title{
DIASPORA DAN HIBRIDITAS \\ DALAM ROMAN SALAH ASUHAN KARYA ABDOEL MOEIS DAN DALAM NOVEL KEBERANGKATAN KARYA NH. DINI
}

\author{
Yati Sugiarti \\ FBS Universitas Negeri Yogyakarta \\ e-mail: artissa@yahoo.de
}

\begin{abstract}
ABSTRAK
Penelitian ini bertujuan mengungkap dan mendeskripsikan identitas diaspora dan hibriditas tokoh utama dalam kedua karya amatan. Sumber data penelitian adalah roman Salah Asuhan karya Abdoel Moeis dan Keberangkatan karya Nh. Dini. Teknik pengumpulan data dilakukan dengan cara membaca objek amatandengan tahapan survei, terpilah dan terpilih. Analisis data dilakukan dengan memilah kategorisasi mana yang termasuk ke dalam diaspora dan mana yang termasuk ke dalam hibriditas. Setelah memilah kategorinya, data tersebut dipaparkan dengan teknik deskriptif kualitatif. Hasil penelitian menunjukkan: (1) bentuk hibriditas tokoh Hanafi dalam roman Salah Asuhan karya Abdoel Moeis dan tokoh Elisabet Frissart dalam novel Keberangkatan karya Nh. Dini meliputi: a) hibriditas bahasa, b) hibriditas sistem kemasyarakatan, c) hibriditas gaya hidup, dan d) hibriditas mata pencaharian (2) Diaspora yang menyangkut tokoh Hanafi bukanlah dalam pengertian yang sebenarnya. Dia tidak pernah terusir "secara fisik" dari tanah leluhurnya. Sementara itu, Elisabet Frissart adalah diasporian murni. Baik secara "fisik" maupun secara "mental" dia terusir dan tercerabut dari tanah asalnya dan dari tanah tempat dia lahir.
\end{abstract}

Kata kunci: diaspora, hibriditas

\section{DIASPORAAND HYBRIDITY IN MOEIS' SALAH ASUHAN AND DINI'S KEBERANGKATAN}

\begin{abstract}
This research reveals and describes the diaspora identity and hybridity of the main characters in the two analyzed novels. The sources of the data are Moeis' Salah Asuhan and Dini's Keberangkatan. The data collecting technique was conducted by observing and surveying the objects and selecting and choosing the information related to diaspora and hybridity. The selected data were analyzed by using qualitative-descriptive technique. The results show that (I) the forms of hibridity of the character Hanafi in Moeis' Salah Asuhan and the character Elisabet Frissart in Dini's Keberangkatan are a) the hybridity of language, b) the hibridity of the society system, c) the hybridity of lifestyles, and d) the hibridity of livelihoods; and (II) the diaspora related to the character Hanafi is not the diaspora in its real meaning as he is never phisically evicted from his hometown. Elisabet Frissart is a real diasporian as she is both physically and mentally evicted from her home town.
\end{abstract}

Keywords: diaspora, hybridity

\section{PENDAHULUAN}

Pada masa penjajahan, Belanda membagi masyarakat menjadi tiga strata, yakni Belanda dan masyarakat Eropa lainnya di tempat teratas, Indo dan Cina di tempat kedua, dan pribumi menempati strata terbawah. Dunia Indo adalah dunia simalakama, sebuah pasangan kembar yang saling bertentangan. Seorang Indo, di luar kemauannya, terjebak dalam dua dunia yang saling bermusuhan. Seorang Indo-Belanda bukan orang Belanda, dan juga bukan orang Indonesia. Lalu ia berada di mana? Berdiri sebagai orang 
Belanda, ia akan dimusuhi orang Indonesia dan dicurigai sebagai orang Belanda. Berdiri sebagai orang Indonesia, ia akan dimusuhi oleh pihak Belanda dan dicurigai pihak Indonesia. Seorang Indo sebenarnya memiliki peluang menjadi manusia transenden, justru karena ia 'tidak di sini', maupun 'tidak di sana', namun juga 'di sini' sekaligus 'di sana'. Seorang Indo adalah 'dunia tengah'. Hal ini akan menimbulkan persoalan kebudayaan. Keadaan 'tidak di sini' dan 'tidak di sana', namun sekaligus ' di sini' dan juga ' di sana' dalam teori poskolonial disebut dengan istilah diaspora dan persoalan budaya campuran disebut hibriditas.

Dekat dengan kemerdekaan seorang Indo juga dimusuhi dan dicurigai. Banyak kaum Indo yang terpaksa harus keluar dari Indonesia, walaupun sebagian besar dari mereka tidak mengenal Belanda sebagai negeri leluhur mereka (Kartodirdjo, 1975). Akan tetapi, politik pada masa itu tidak memihak kepada kelompok Indo. Pada zaman Reformasi, kelas Indo mendapat tempatnya kembali. Wajah Indo, yang putih, mulus, rambut pirang, postur tubuh tinggi, dianggap sebagai simbol kecantikan/ kegantengan. Wajahwajah Indo mendominasi hampir semua ruang publik Indonesia. Keberadaan kelas Indo dalam realita telah menghasilkan inspirasi pengarang untuk menjelmakannya dalam karya sastra, diantaranya Salah Asuhan karya Abdoel Moeis dan Keberangkatan karya Nh. Dini

Tokoh Hanafi dalam roman amatan yang telah menempuh pendidikan model Belanda mengalami kegamangan identitas. Dalam dirinya terjadi satu pergumulan. Jiwanya yang bersifat Belanda terkungkung oleh tubuh wadahnya yang pribumi. Sementara itu, dalam $\mathrm{Ke}$ berangkatan justru sebaliknya. Elisa beribu Indo dari Malang. Kakek dari pihak ibu adalah orang Belanda yang hidup bersama dengan seorang buruh perkebunan. Sementara itu, Fred Frissart yang selama ini disangka ayah kandungnya, ternyata adalah adik ayahnya. Jadi, pamannya sendiri yang kemudian kawin dengan ibunya. Di samping itu, ada laki-laki Jawa bernama Talib, seorang pelukis, mengaku sebagai ayah kandungnya. Hal ini disebabkanibu Elisa sering bergaul dengan berbagai macam pria. Dari urutan keluarga semacam itu Elisa merasa tidak memiliki akar yang kuat.
Semua bentuk hibriditas yang dilakukan Hanafi merupakan upaya dirinya untuk mencapai derajat yang lebih tinggi dari pribumi, yakni supaya sejajar dengan bangsa Indo dan Eropa sebagai penjajah pada saat itu. Sementara itu, bentuk hibriditas Elisabet Frissart yaitu hanya ingin memiliki status kewarganegaraan yang jelas dan masuk ke dalam orbit pribumi. Jadi, dia ingin memiliki akar keluarga yang kuat.

Baik Hanafi maupun Elisabet Frissart merasa memiliki identitas yang terbelah. Dirinya merasa "berada" di dua tempat, sekaligus juga "tidak berada", yakni di tempat pribumi dan di tempat bangsa Eropa. Diaspora Hanafi bukanlah dalam pengertian yang sebenarnya. Dia tidak pernah terusir "secara fisik" dari tanah leluhurnya, dia hanya terusir secara "mental". Sementara itu, Elisabet Frissart adalah diasporian murni. Baik secara "fisik" maupun secara "mental" dia terusir dan tercerabut dari tanah asalnya dan dari tanah tempat dia lahir.

Teori yang dipakai dalam penelitian ini adalah teori poskolonial yang bertitik tolak pada Orientalisme-nya Said (1996), dengan titik berat pada diaspora dan hibriditas. Teori ini bertumpu pada konstruksi historis terhadap masyarakat dan budaya Timur sebagai 'sesuatu yang asing'. Timur dianggap sebagai sejenis objek yang asing, lemah, bodoh, primitif. Oleh karena itu, Timur memerlukan Barat yang kuat dan rasional untuk membebaskannya dari kelemahan, kebodohan, dan keterbelakangan. Dengan demikian, Barat memiliki legitimasi untuk memandang, mengatur, dan menata Timur. Binarisme yang biasanya digunakan untuk merekonstruksi perbedaan identitas antara hitam/putih, sang diri/ sang lain dan sebagainya (King, 2001: v-vi)

\section{METODE PENELITIAN}

Subjek penelitian ini adalah novel $\mathrm{Ke}$ berangkatan karya Nh. Dini dan roman Salah Asuhan karya Abdoel Moeis. Penelitian ini dapat digolongkan ke dalam penelitian kepustakaan. Oleh karena itu, teknik pengumpulan datanya dilakukan dengan cara membaca secermat mungkin objek amatan. Pembacaan dilakukan dengan cara survei, terpilah dan terpilih,menandai dan mengutip ekspresi-ekspresi yang menyangkut diaspora dan hibriditas. Data-data tersebut di- 
catat dalam kartu data

Selanjutnya, ekspresi yang menyangkut diaspora dan hibriditas yang dicatat dalam kartu data tersebut dicantumkan pula nomor halaman, dan objeknya apa. Analisis data dilakukan dengan memilah kategorisasi mana yang termasuk ke dalam diaspora dan mana yang termasuk ke dalam hibriditas. Setelah memilah kategorinya, data tersebut dipaparkan dengan teknik deskriptif kualitatif.

\section{HASIL DAN PEMBAHASAN}

Dalam masyarakat terjajah terjadi alienasi kultural yang berporos pada ambivalensi identifikasi fisik. Tatapan mata seorang kulit putih, demikian Fanon, dapat memporakporandakan tubuh manusia berkulit hitam. Artinya, dalam pandangan manusia kulit putih, seorang manusia kulit hitam dipandang sebagai kanibalisme, memiliki ras yang parah/rusak, dan mengalami defisiensi intelektual. Dengan sendirinya manusia kulit hitam merasa dirinya tidak hanya ditelanjangi, tetapi diamputasi, diciprati seluruh tubuhnya dengan darah hitam dan ingin menjauhkan diri dari eksistensinya. Keadaan demikian menunjukkan sebuah 'konstelasi kegilaan': orang hitam diperbudak dengan perasaan inferioritasnya, dan orang putih diperbudak oleh perasaan superioritasnya Malcolm X (Synnott, 2003: 65) menjelaskan:

Orang kulit putih sangat ahli membuat Anda dan kalian membenci identitas Afrika kita, karasteristik Afrika kita. Anda tahu bahwa kita telah menjadi sebuah masyarakat yang membenci karakteristik Afrika kita. Kita membenci kepala kita, kita membenci bentuk hidung kita, kita menginginkan salah satu hidung kita seperti anjing yang panjang seperti itu; kita benci warna kulit kita, membenci darah Afrika yang mengalir di dalam pembuluh-pembuluh darah kita. Dan dalam kebencian terhadap ciri khas, kulit, dan darah kita, kita dapat bertanya, mengapa kita tidak mampu menghentikan kebencian tersebut. Karena itu kita akan terus membenci diri kita sendiri.
Keadaan serba tidak menyenangkan ini membuahkan tiga kondisi yang mendasari proses identifikasi dalam analisis tentang hasrat atau keinginan. Pertama, untuk menjadi ada/ eksis, seseorang harus masuk ke dalam tubuh, ke dalam cara pandang, dan ke dalam lokasi atau tempat sang lain. Kedua, ruang identifikasi yang sesungguhnya yang ada dalam tuntutan dan hasrat adalah ruang yang terbelah. Yang dimaksud terbelah di sini adalah fantasi pribumi menempati ruang sang lain/pemukin/settler. Sementara itu, pribumi tetap mempertahankan dan menjaga ruang miliknya. Kulit hitam topeng putih (schwarze Haut, weisse Masken) bukanlah pembagian yang murni. Hal ini merupakan gambaran tubuh yang digandakan, disembunyikan di dalam dua tempat dalam satu kurun waktu. Ketiga, persoalan identifikasi tidak pernah merupakan penegasan dari identitas yang telah terbentuk sebelumnya, bukan pula penyempurnaan sang diri. Tuntutan terhadap identifikasi - yaitu menjadi 'sang lain', memerlukan representasi subjek dalam tuntutan yang berbeda dari sang lain (Bhabha, 1994: 44).

Tempat dan ketidakbertempatan (Ashcroft, 1995: 391) adalah hal-hal krusial dalam wacana poskolonial. Tempat dalam hal ini bukan sebuah 'lanskap'. Tempat dalam poskolonial lebih diartikan sebagai interaksi yang kompleks dari bahasa, sejarah, dan lingkungan. Tempat pertama-tama ditandai oleh perasaan "ketidakbertempatan" oleh mereka yang masuk ke dalam sebuah koloni, atau lebih luas lagi sebuah perasaan ketidakbertempatan dalam bahasa yang dibawa penjajah, sebuah jurang pemisah antara lingkungan 'beradab/berpengalaman' dan deskripsi bahasa yang tersedia. Kedua, tempat ditandai oleh perasaan penamaan kultural yang luar biasa dalam konstruksi ruang. Perasaan ketidakbertempatan yang 'pas' antara bahasa dan ruang/tempat, mungkin dialami oleh orang yang menggunakan bahasa Inggris sebagai bahasa ibu, dan yang memakai bahasa Inggris sebagai bahasa kedua. Dalam kedua kasus tersebut, perasaan terputus dari 'tanah air' secara historis dan yang diciptakan oleh ketidaksesuaian antara bahasa, pengalaman 'ketidakbertempatan' membangkitkan ketegangan dalam bahasa. Dengan demikian, tempat adalah hal 'ikutan' dari perbedaan, pengingat yang terus menerus 
dari keterbelahan, dan penembusan hibriditas dari penjajah dan terjajah.

Dalam masyarakat poskolonial, hibriditas (Ashcroft, 1995: 183) muncul sebagai akibat momen kesadaran atas penindasan kultural, yaitu ketika kekuatan kolonial menjajah untuk mengkonsolidasi kontrol politis dan ekonomis, atau ketika pemukim-penjajah menguasai orangorang pribumi dan memaksa mereka untuk 'berasimilasi' ke dalam pola-pola masyarakat yang baru. Hibriditas muncul pada periode akhir ketika pola-pola imigrasi dari masyarakat metropolitan dan dari pengaruh wilayah imperial lainnya (sebagai contoh kuli kontrak dari India dan Cina) meneruskan memproduksi kompleksitas kultural.

Susanto (2007: 1-2) menyebutkan empat pengertian diaspora. Pertama, diaspora didefinisikan sebagai kekuatan kolektif dari persebaran keagamaan dan kelompok etnis. Kedua, diaspora diartikan sebagai peran bermain untuk memunculkan memori kolektif yang ditransmisikan baik dalam fakta kesejarahan yang dipercepat persebarannya maupun warisan budaya yang seringkali diasosiasikan dengan keagamaan. Ketiga, karena kaum diapora mengalihkan warisan budaya atau tradisi untuk dijadikan kekuatan satu identitas, ciri-ciri diaspora menjadi satu kelompok yanhg mampu bertahan sebagai minoritas melalui trasnmisi budaya tersebut. Keempat, penyebutan satu kelompok sebagi kaum diaspora tergantung dari faktor waktu, misal pembunuhan suku bangsa, peperangan, pengusiran, ekonomi, politik, bencana alam dan lain-lain, baik di masa lalu dan masa kini dari kelompok yang meninggalkan wilayah asal atau berada di luar wilayah asal tersebut dianggap sebagai kaum diasporian.

Ruang diaspora sebagai sebuah kategori konseptual bukan hanya 'didiami' (inhabited) oleh mereka yang bermigrasi dan anak keturunannya, tetapi juga secara bersamaan oleh mereka yang dikonstruksikan dan direpresentasikan sebagai pribumi. Dengan kata lain, konsep ruang dispora meliputi keterlibatan, keterjalinan penyebaran genealogis dengan mereka yang 'tetap berada di tempat'. Ruang diaspora adalah sebuah situs, yang menempatan pribumi lebih merasa sebagai diasporian, dan diasporian lebih merasa sebagai pribumi.
Konsep hibriditas membuktikan percampuran kultural dan kemunculan bentukbentuk baru identitas. Hibriditas dibagi menjadi hibriditas struktural dan hibriditas kultural. Hibriditas struktural mengacu pada macammacam situs hibriditas sosial dan institusional, sebagai contoh, wilayah perbatasan atau kotakota seperti Singapura dan Miami. Sementara itu, hibriditas kultural membedakan respons kultural yang bergerak dari asimilasi, melalui bentuk-bentuk pemisahan, menuju ke hibriditas yang mendestabilkan dan mengaburkan batas-batas kultural. Baik hibriditas struktural yang memperluas jarak pendapat manusia secra organisasional, maupun hibriditas kultural yang menyangkut terbukanya 'masyarakat terbayang' merupakann tanda-tanda peningkatan lintas batas. Akan tetapi, kedua bentuk hibriditas ini tidak merepresentasikan penghapusan batasbatas, sehingga orang perlu bersikap hati-hati, baik terhadap perbedaan kultural atau terhadap bentuk-bentuk identifikasi yang melibatkan pengakuan tentang persamaan.

Untuk dapat memasuki lingkungan masyarakat Eropa, Taylor (dalam Cote, 2004: 4-6) mengemukakan mekanisme yang lain, yaitu melalui penyeberangan batasan ras, agama, dan asal-usul melalui emansipasi formal pembaptisan kristiani dan menikah dengan orang Eropa. Bagi para wanita, untuk menyeberangi batasan ras, agama, dan asal-usul ini, harus melakukan tali perkawinan dengan seorang pria Eropa. Atau paling tidak, para wanita ini menjadi nyai, yang fungsi awalnya hanya menjadi partner seks bagi pria Eropa. Ketika seorang perempuan pribumi menjadi nyai, kehidupan ekonominya otomatis menjadi lebih baik. Ia hidup lebih nyaman di samping lebih 'disegani' daripada sebelumnya. Akan tetapi, kedudukan sebagai nyai amat lemah karena dia tidak memiliki hak untuk mengasuh anaknya sendiri dari hasil hubungan dengan pria Eropa tersebut. Sementara itu, pada pria pribumi, untuk mentransformasikan identitas dan statusnya bukan melalui perkawinan, melainkan melalui konversi ke agama majikan utamanya atau agama yang dianut elit penguasa, kepada siapa dia ingin menyertakan dirinya dalam rangka memajukan karir dan prospeknya (Taylor dalam Cote, 2004: 8, 22). Laki-laki berbakat yang berasal dari kalangan biasa dan 
perempuan budak yang mencoba menolak kemiskinan berusaha untuk mentransformasikan identitas mereka dengan memasuki lingkungan yang berbeda.

Konsekuensi dari perkawinan campuran ini adalah terciptanya kelompok sosial yang baru dan menciptakan sebuah produk kebudayaan yang bukan Eropa dan bukan pula pribumi, melainkan memiliki asal-usul dari warisan keduanya. Percampuran darah ini menimbulkan budaya dan gaya hidup Belanda-Pribumi atau gaya Indis. Sementara itu, campuran budaya Belanda dan budaya pribumi yang didukung oleh segolongan masyarakat Indonesia disebut budaya Indis (Soekiman, 2000: 5-8). Dalam perkembangannya, Indis juga dianggap sebagai identitas campuran yang merupakan partner atau bahkan sampai tingkat tertentu dapat disebut lawan dari "Belanda totok" yang berusaha lepas dari Indonesia dan ingin terus ingin masuk dalam identitas Barat. Pada konteks ini, Indis seolah-olah identik dengan Indo walaupun secara konseptual dan historis dua hal itu berbeda (Purwanto dalam Cote, 2004: vii).

Bahasa bagi wacana poskolonial merupakan landasan pokok dari perjuangan wacana poskolonial karena proses kolonisasi berawal pada bahasa. Analisis tekstual poskolonial difokuskan pada suatu cara, yakni bahasa penjajah dicocokkan, diadaptasi, dicangkokkan, dihibridasi, 'direndahkan', bahkan ditolak dalam proses kolonisasi. Strategi demikian dirancang untuk mencabut otoritas versi standar dari bahasa penjajah dan wacana-wacana yang menyertainya dan secara serempak mengembangkan versi lokal yang berbicara pada kemungkinankemungkinan dari konteks nonmetropolitan sang subjek, baik itu subjek pemukim/settler yang harus mengadaptasi bahasa mereka ke dalam tempat atau pengalaman baru maupun subjek pribumi yang harus menamai kembali tempat atau pengalaman mereka ke dalam bahasa yang dipaksakan (Ashcroft 1995: 283). Penguasaan bahasa bangsa penjajah oleh bangsa terjajah membawa keuntungan tersendiri bagi mereka. Kaum terjajah dapat memahami dan masuk ke dalam budaya yang dibawa oleh bangsa penjajah. Akan tetapi, penjajahan di Indonesia agak berlainan dengan di India. Di Indonesia, orang yang dapat menguasai bahasa Belanda hanya sebagian kecil saja. Hal ini disebabkan bahasa Belanda hanya diajarkan kepada golongan atas di Indonesia.

Hibriditas bahasa yang dilakukan Hanafi dalam berhubungan dengah temanteman Eropanya, khususnya Belanda, telah memungkinkan Hanafi memasuki orbit kaum penjajah, memasuki dan memahami budayanya. Bentuk hibriditas bahasa yang dilakukan Hanafi yaitu dengan sering memakai bahasa Belanda. Dengan demikian, hibriditas bahasa telah mengangkat derajat Hanafi menjadi setara dengan bangsa penjajah.

Elisa dalam Keberangkatan berbuat sebaliknya. Semenjak kabur dari keluarganya dan memutuskan untuk tinggal di asrama bersama para pramugari lainnya, dia selalu berusaha memakai bahasa Indonesia. Terkadang katakata Belanda muncul ketika dia bercakap-cakap dengan kaum pribumi. Akan tetapi, itu bukan menandakan bahwa pengetahuan dia melebihi kaum pribumi atau dirinya lebih bermartabat dari kaum pribumi. Hal ini justru sebaliknya. Manakala dia mengalami sesuatu yang sangat memukul atau membahagiakannya, maka bahasa yang dia kenal sejak kecil, sebagai sesuatu yang kodrat akan muncul ke permukaan.

Hibriditas yang dilakukan Hanafi dalam sistem kemasyarakatan yang meliputi sistem perkawinan, sistem kekerabatan, dan sistem pergaulan telah mendorong Hanafi untuk selalu berseberangan paham dengan bangsanya sendiri. Bentuk hibriditas sistem kemasyarakatan pada Hanafi yaitu bergaul dengan orang-orang Eropa, menikah dengan Indo, menganut kekerabatan nuclear family. Akibat yang diperoleh melalui hibriditas tersebut, Hanafi menjadi arogan. Pada akhirnya, dia bersikap dan bertingkah laku persis seperti Barat yang memperlakukan Timur. Hanafi mengangap dirinya hebat, berkuasa, liberal, dan modern. Dia melecehkan adat perkawinan kampungnya dengan menyebutnya sebagai handelstransacties. Sistem kekerabatan Minangkabau dianggapnya terlalu banyak turut campur dalam kehidupan pribadinya. Sementara itu, pergaulannya dengan bangsa pribumi dianggapnya sebagai suatu kesia-siaan belaka.

Dalam lingkungan kerja Elisa lebih memilih untuk bergaul dengan para pegawai atau awak pesawat yang berasal dari Jawa. 
Dia ingin lebih mengenal dan mengerti cara hidup dan cara berpikir mereka, laki-laki dan perempuan. Adat istiadat yang sama sekali asing baginya mulai ditelisik dan diperinci kesamaan dan perbedaannya. Memang banyak kebiasaan aneh yang harus dia pelajari (Dini, 1977: 38). Dalam memilih calon pendamping pun dia lebih suka orang pribumi, terutama sekali dari suku Jawa. Menurutnya, orang Jawa yang telah hidup bertahun-tahun dan mengerti cara-cara adat pribumi begitu mengesankan dirinya. Dari semua alasan itu, dia berharap seorang suami yang bisa menjadikannya seorang anak Indonesia tulen. Dalam lingkungan pergaulannya, Elisa dikenal sebagai seorang gadis peranakan yang "terlalu keIndonesiaan" dalam segala hal (Dini, 1977).

Dari hasil analisis hibriditas gaya hidup terungkap bahwa yang dilakukan Hanafi yang menyangkut cara makan, olah raga, dan gaya penataan rumah yang terlihat dari relasi antara Hanafi-Corrie, Hanafi-ibunya, Hanafi-masyarakat Eropa/Belanda, dan Hanafimasyarakat Minangkabau ini semata-mata untuk menaikkan martabatnya agar sederajat dengan kaum penjajah.

Hibriditas gaya hidup yang dilakukan tokoh Elisa dalam novel Keberangkatan yang menyangkut tata cara, adat istiadat, serta kebiasaan berkelakuan, seperti misalnya tata cara makan, tata cara berpakaian, tata cara menata rumah, dan tata cara pergaulan tidak jauh berbeda dengan penduduk pribumi lainnya. Tidak ada perbedaan mencolok antara pribumi dan Indo seperti yang tampak pada Salah Asuhan. Hanya ketika berada "di dalam lingkungannya" sering terjadi pesta-pesta yang mengharuskan para undangan berdansa, laki-laki dan perempuan berpegangan tangan, laki-laki memeluk pingang perempuan. Dansa seperti itu pun kerap diikuti oleh Elisa dengan para pribumi lainnya. Akan tetapi, dalam pandangan Elisa, para lekilaki pribumi lebih mempergunakan kesempatan dansa sebagai alat perangsang. Semenjak itu, Elisa tidak pernah lagi menghadiri pesta dansa yang diadakan kaum pribumi. Dia malah lebih suka nonton pertunjukkan wayang.

Dengan jabatan barunya di Betawi sebagai Commies pada Departemen vanBinnenlandsch Bestuur dan seiring dengan diperolehnya hak sebagai Eropa, hibriditas mata pencaharian yang dilakukan Hanafi semakin menaikkan martabat dirinya di mata kaum bumiputra dan di mata orang Eropa sendiri. Hal ini membuat kebanggan pada dirinya karena tidak setiap pribumi, walaupun dia sudah menempuh ujian pegawai tingkat tinggi (grootambtenaars-examen), dapat memperoleh pekerjaan di lingkungan pemerintah kolonial. Pada Elisa, hibriditas bahasa, hibriditas sistem kemasyarakatan dan hibriditas gaya hidup, dalam hibriditas mata pencaharian pun tidak tersirat maksud bahwa kaum Indo lebih tinggi derajatnya dari kaum pribumi. Elisa digambarkan sebagai seorang pramugari udara, sebuah pekerjaan yang juga banyak dilakukan oleh kaum pribumi.

Hanafi, tokoh utama dalam roman amatan mengalami kegamangan dalam hidupnya. Dalam dirinya muncul permasalahan identitas. Seluruh masa kecilnya dihabiskan di keluarga Belanda. Pendidikannya ditempuh di sekolah model Belanda di Betawi. Dengan sendirinya dalam dirinya tumbuh identitas yang terbelah. Dalam jiwanya terdapat identitas Belanda, yakni cita-citanya, perasaannya, cara berpikirnya, aspirasinya, dan tingkah lakunya menunjukkan identitas Belanda. Sementara itu, jiwanya terkungkung oleh wadag tubuhnya yang pribumi, yang berbeda dengan tubuh yang dimiliki oleh orang kulit putih. Kulitnya yang berwarna, yang dalam darahnya juga mengalir darah pribumi asli, menjadi semacam phobia yang membuatnya ingin menjauhi eksistensinya. Karena bentuk fisik yang dimilikinya itu, dia menyesali dirinya terlahir sebagai pribumi. Untuk mengatasi permasalahan ini, kemudian muncul hasrat dalam dirinya agar menjadi sama dengan identitas yang diidealkan. Proses identifikasi terhadap 'sang lain' ini dilakukan dengan cara masuk ke dalam tubuh, ke dalam cara pandang, ke dalam ruang 'sang lain'. Salah satu cara yang dilakukan Hanafi adalah dengan mengajukan gelijkgesteld, yakni mengajukan permohonan supaya haknya dipersamakan dengan orang-orang Eropa. Demikian pula yang dialami tokoh Elisabet Frissart dalam novel Keberangkatan yang terbit pada tahun 1970an. Keberangkatan menceritakan kegagalan percintaan seorang gadis Indo bernama Elisabet Frissart dengan seorang pemuda Jawa. Dia meninggalkan Indonesia menuju ke 
negeri Belanda, tempat keluarganya menetap setelah terjadi pemulangan orang-orang kulit putih dan Indo yang dilakukan oleh pemerintah Indonesia pada masa pasca kemerdekaan. Peneliti melihat, bukan karena percintaannya yang gagal yang menyebabkan tokoh utama meninggalkan Indonesia, melainkan lebih kepada alasan "ketidakbertempatan" yang menjadi penyebab keberangkatannya tersebut. Tokoh utama berusaha masuk ke dalam orbit Asia.

\section{PENUTUP}

Bentuk hibriditas tokoh Hanafi dalam roman Salah Asuhan dan bentuk hibriditas tokoh Elisabet Frissart dalam novel Keberangkatan meliputi hibriditas bahasa, hibriditas gaya hidup, hibriditas sistem kemasyarakatan, dan hibriditas mata pencaharian. Kesemua bentuk hibriditas tersebut bagi tokoh Hanafi merupakan upaya dirinya untuk mencapai derajat yang lebih tinggi dari pribumi, yakni supaya sejajar dengan bangsa Indo dan Eropa sebagai penjajah pada saat itu. Sementara itu, bentuk hibriditas bagi tokoh Elisa agak berlainan. Dia tidak memiliki keinginan untuk memiliki derajat yang lebih tinggi dalam masyarakat. Dia hanya ingin memiliki status kewarganegaraan yang jelas dan masuk ke dalam orbit pribumi.

Baik Hanafi maupun Elisa keduanya mengalami kegamangan dalam menyikapi identitas dirinya. Keduanya memiliki identitas yang terpecah. Oleh karenanya, untuk dapat merasa "berketempatan" keduanya mencoba keluar dari orbitnya. Hanafi meninggalkan identitas kepribumiannya, Elisa meninggalkan identitas keeropaannya. Diaspora Hanafi bukanlah dalam pengertian yang sebenarnya. Dia tidak pernah terusir "secara fisik" dari tanah leluhurnya. Dia lahir, besar dan tumbuh di tanah kelahirannya. Akan tetapi, "secara mental" dia telah terusir dari lingkungannya, baik itu lingkungan pribumi, maupun lingkungan nonpribumi, dalam hal ini orang Eropa. Keterusiran itu mebuat dirinya merasa "tidak berketempatan", merasa tidak memiliki tanah tempat berpijak, karena di lingkungan pribumi dia tidak diterima, di lingkungan kelompok Eropa dan Indo pun dia ditolak walaupun telah melakukan proses gelijkstelling, yakni menyamakan kedudukan- nya setara dengan bangsa Eropa. Sementara itu, Elisabet Frissart adalah diasporian murni. Nenek moyangnya berasal dari negeri Belanda. Dia lahir, tinggal, dan besar di Indonesia, tanah yang jauh dari asal nenek moyangnya. Dia tidak mengenal tanah leluhurnya. Di tanah tempat dia lahir dan tumbuh berkembang, kehadirannya tidak diterima oleh penguasa pada saat itu. Sementara itu, dia juga merasa asing dengan tanah leluhur yang sama sekali tidak dikenalnya. Dengan demikian, baik secara "fisik" maupun secara "mental" dia terusir dan tercerabut dari tanah asalnya dan dari tanah tempat dia lahir.

\section{Saran}

Berdasarkan hasil penelitian, terjadi "keunikan" yang dialami oleh kedua tokoh dalam karya amatan. Orang pribumi ingin meninggalkan orbit kepribumiannya, orang Eropa ingin meninggalkan orbit ke-Eropaan-nya. Untuk itulah perlu diadakan penelitian lebih lanjut terutama yang menyangkut permasalahan kaum diasporian. Penelitian lanjutan ini dapat berupa kajian mengenai karya sastra, ataupun kajian mengenai kaum diasporian yang memang dalam fakta kehidupan ada di tanah air kita, seperti misalnya kaum China keturunan.

\section{DAFTAR PUSTAKA}

Ashcroft, Bill, Griffiths, Garren and Tiffin, Helen. 1995. The Postcolonial Studies Reader. London: Routledge. 1994. The Location of Culture, London: Routledge

Cote, Joost, dan Westerbeek, Loes (ed.). 2004. Recalling the Indies, Kebudayaan Kolonial dan Identitas Poskolonial. Yogyakarta: Syarikat.

Cote, Joost. 2004. "Romanisasi Hindia Belanda; Konstruksi Sastra tentang Tempo Doeloe" dalam Cote, Joost, dan Westerbeek, Loes (ed.) 2004. Recalling the Indies, Kebudayaan Kolonial dan Identitas Poskolonial.Yogyakarta: Syarikat.

Dini, Nh. 1977. Keberangkatan. Jakarta: PT Pustaka Jaya.

Kartodirdjo, Sartono, dan Notosusanto, Nugroho. 1975. Sejarah NasionalIndonesia. 
Jilid V. Jakarta: Deparrtemen Pendidikan dan Kebudayaan.

King, Richard. 2001. Agama, Orientalisme, dan Poskolonialisme (penerjemah Agung Prihantoro). Yogyakarta: Qalam.

Said, Edward. 1996. Orientalisme (penerjemah Asep Hikmat). Bandung: Pustaka.

Soekiman, Djoko. 2000. Kebudayaan Indis dan Gaya Hidup Masyarakat Pendukungnya di Jawa (Abad XVIII-Mediao Abad $X X)$. Yogyakarta: Galang Press.
Susanto, Dwi. 2007. Pengalaman Diaspora Peranakan Cina di Indonesia: Satu Kajian Terhadap Berjuang dan Masjarakat Karya Liem Khing Hoo. Makalah pada Seminar Rumpun Sastra, FPB UNY, 2007.

Synnott, Anthony. 2003. Tubuh Sosial, Simbolisme, Diri dan Masyarakat. Dialihbahasakan oleh Yudi Susanto.Yogyakarta: Jalasutra. 